\title{
Analisis Kinerja Keuangan Pada PT. Bank Pembangunan Daerah Sumatera Selatan dan Bangka Belitung
}

\author{
Oktalia Rengganis ${ }^{1}$, Reva Maria Valianti ${ }^{2}$, Oktariansyah $^{3}$ \\ ${ }^{1}$ Fakultas Ekonomi Universitas PGRI Palembang \\ 2Fakultas Ekonomi Universitas PGRI Palembang, revavalianti@univpgri-palembang.ac.id \\ ${ }^{3}$ Fakultas Ekonomi Universitas PGRI Palembang, rianbro82@univpgri-palembang.ac.id
}

\begin{abstract}
The data observed in this study are financial statements in the form of financial position reports and income statements from 2011 to 2015. Data analysis and discussion were carried out using quantitative descriptive analysis methods and qualitative approaches, namely by analyzing risk profile, earnings and capital. The results of this study indicate that the LDR level of PT. Bank Sumsel Babel, namely in 2011 and 2012 amounted to $76 \%$ and $77 \%<85 \%$ in 2013 and 2014 at $95 \%$ and $89 \%<100 \%$ In 2015 the LDR (Loan To Deposit Ratio) was 101\% <120\%. The NPL (Non Performing Loan) Ratio of Bank Sumsel Babel in 2011 was $1.5 \%<2 \%$ in 2012 and 2014 amounted to $6.9 \%$ and $7.6<8 \%$ in 2013 amounted to $9 \%>8 \%$ in 2015 by $4.4 \%<5 \%$. BOPO Ratio (Operational Cost to Operational Income) Bank Sumsel Babel in 2011, 2012, 2013, 2014 and 2015 was $81 \%, 84 \%, 86 \%, 82 \%$ and $81 \%<90 \%$. The ROA (Return on Assets) ratio of Bank Sumsel Babel in 2011, 2012, 2013, 2014 and 2015 was 2\%, 2\%, 2\%, 2\% and 3\%> $2 \%$. The ROE (Return on Equity) ratio of Bank Sumsel Babel in 2011 was 26\%>20\%. whereas in 2012, 2013, 2014 and 2015 it was 18\%, 13\%, 16\% and 17\% <20\%. The CAR (Capital Adequacy Ratio) of Bank Sumsel Babel in 2011 and 2012 was 12\% and 14\% <15\%. Whereas in 2013, 2014 and 2015 amounted to $15 \%, 18 \%$ and $20 \%>15 \%$. So it can be interpreted that the level of liability of PT Bank Sumsel Babel is considered not good. because the level of the NPL ratio is high, this means that the company has not been able to utilize its funds effectively and efficiently.
\end{abstract}

Keywords: Loan To Deposit Ratio, Non Performing Loan, BOPO, Return On Assets, Return On Equity, Capital Adequacy Ratio.

\begin{abstract}
ABSTRAK
Data yang diamati pada penelitian ini merupakan laporan keuangan berupa laporan posisi keuangan dan laporan laba rugi dari tahun 2011 sampai tahun 2015. Analisis data dan pembahasan dilakukan dengan menggunakan metode analisis deskriptif kuantitatif dan pendekatan kualitatif yaitu dengan menganalisis risk profile, earnings dan capital. Hasil penelitian ini menunjukkan bahwa tingkat LDR PT. Bank Sumsel Babel yaitu pada tahun 2011 dan 2012 sebesar $76 \%$ dan $77 \% \leq 85 \%$ pada tahun 2013 dan 2014 sebesar 95\% dan 89\% < 100\% Pada tahun 2015 Rasio LDR (Loan To Deposit Ratio) sebesar $101 \% \leq 120 \%$. Rasio NPL (Non Performing Loan) Bank Sumsel Babel pada tahun 2011 sebesar $1,5 \% \leq 2 \%$ pada tahun 2012 dan 2014 sebesar $6,9 \%$ dan $7,6 \leq 8 \%$ pada tahun 2013 sebesar $9 \% \geq 8 \%$ pada tahun 2015 sebesar 4,4\% $\leq 5 \%$. Rasio BOPO (Biaya Operasional Pendapatan Operasional) Bank Sumsel Babel pada tahun 2011, 2012, 2013, 2014 dan 2015 sebesar $81 \%, 84 \%, 86 \%, 82 \%$ dan $81 \% \leq 90 \%$. Rasio ROA (Return On Assets) Bank Sumsel Babel pada tahun 2011, 2012, 2013, 2014 dan 2015 sebesar 2\%, 2\%, 2\%, 2\% dan 3\% $\geq 2 \%$. Rasio ROE (Return On Equity) Bank Sumsel Babel pada tahun 2011 sebesar $26 \% \geq 20 \%$. sedangkan pada tahun 2012, 2013, 2014 dan 2015 sebesar 18\%, 13\%, 16\% dan 17\% $\leq 20 \%$. Rasio CAR (Capital Adequacy Ratio) Bank Sumsel Babel pada tahun 2011 dan 2012 sebesar 12\% dan 14\% $\leq 15 \%$. Sedangkan pada tahun 2013, 2014 dan 2015 sebesar 15\%, 18\% dan 20\% $\geq 15 \%$ Maka dapat diartikan bahwa tingkat liability PT Bank Sumsel Babel dinilai belum baik. karena tingkat rasio NPL tinggi, hal ini berarti perusahaan belum dapat memanfaatkan dananya secara efektif dan efisien.
\end{abstract}

kata kunci : Loan To Deposit Ratio, Non Performing Loan, BOPO, Return On Assets, Return On Equity, Capital Adequacy Ratio. 


\section{A. PENDAHULUAN}

Lembaga perbankan merupakan salah satu sumber perekonomian negara. Dimana kegiatannya sebagai alat intermediasi yakni menghimpun dana dari masyarakat dalam bentuk simpanan dan menyalurkannya kepada masyarakat dalam bentuk kredit, serta memberikan jasa lainnya. Kegiatan menghimpun dan menyalurkan dana merupakan kegiatan pokok bank. Sedangkan tujuan utama bank yaitu memperoleh profitabilitas yang maksimal, sehingga dengan kata lain diperlukan pengelolaan perbankan secara maksimal.

Kinerja keuangan suatu perusahaan menunjukkan kaitan yang cukup erat dangan penilaian mengenai sehat atau tidaknya suatu perusahaan. Perusahaan yang sehat merupakan perusahaan yang memiliki kinerja yang baik, hal ini dapat dilihat dari sisi keuangan maupun sisi manajemennya. Setiap perusahaan yang bertujuan profit oriented pastinya akan selalu memperhatikan kinerja keuangan perusahaannya. Hal ini disebabkan karena dengan kinerja keuangan yang mapan lembaga perbankan akan lebih mampu menarik kepercayaan masyarakat dalam menghimpun dananya.

Kinerja perusahaan dapat dilihat melalui berbagai macam variable atau indikator. Variabel atau indikator yang dijadikan dasar penilaian adalah laporan keuangan perusahaan yang bersangkutan. Informasi posisi dan kinerja keuangan dimasa lalu seringkali digunakan sebagai dasar untuk memprediksi posisi keuangan dan kinerja dimasa depan dan hal-hal lain yang langsung menarik perhatian pemakai seperti pembayaran deviden, upah, pergerakan harga sekuritas dan kemampuan perusahaan untuk memenuhi komitmennya ketika jatuh tempo. Kinerja merupakan hal penting yang harus dicapai oleh setiap perusahaan dimanapun, karena kinerja merupakan cerminan dari kemampuan perusahaan dalam mengelola dan mengalokasikan sumber dayanya.

Laporan keuangan merupakan informasi yang sangat penting karena dari laporan keuangan inilah dapat terlihat kinerja suatu perusahaan. Laporan keuangan ini harus menggambarkan semua data keuangan yang relevan dan telah ditetapkan prosedurnya sehingga laporan keuangan dapat diperbandingkan sehingga tingkat akurasi analisis dapat di pertanggungjawabkan. Salah satu alat untuk mengukur kinerja keuangan suatu perusahaan adalah dengan menganalisis rasio keuangan. Rasio keuangan berguna untuk mengidentifikasi kekuatan dan kelemahan keuangan suatu perusahaan. Perhitungan rasio sangat penting bagi pihak luar yang ingin menilai laporan keuangan suatu perusahaan. Penilaian dititikberatkan pada kemampuan perusahaan untuk memenuhi kewajiban jangka pendek atau likuiditas, solvabilitas, rentabilitas, dan prospek perusahaan di masa depan. Analisa rasio ini berguna juga bagi pihak perusahaan untuk membantu manajer dalam membuat evaluasi mengenai hasil operasi, memperbaiki kesalahan yang terjadi akibat penyimpangan atas rencana yang telah disusun dan menghindari hal-hal lain yang bersifat merugikan lembaga.

Pada tahun 2011 berdasarkan pada Peraturan Bank Indonesia Nomor 13/1/PBI/2011 tentang Penilaian Tingkat Kesehatan Bank Umum, bank wajib melakukan penilaian Tingkat Kesehatan Bank dengan menggunakan pendekatan berdasarkan Risiko (Risk-based Bank Rating). Penilaian Tingkat Kesehatan Bank dilakukan terhadap bank secara individual maupun konsolidasi. Dan penilaian ini disebut dengan metode RGEC (Risk Profile, GCG, Earnings and Capital). Risk profile diukur menggunakan perhitungan Loan to Deposit Ratio (LDR) dan Non 
Performing Loan (NPL). Earnings adalah rasio yang digunakan untuk mengukur kemampuan bank dalam meningkatkan keuntungan, juga untuk mengukur tingkat efisiensi usaha dan rentabilitas yang dicapai bank bersangkutan. Rasio ini juga menunjukkan kemampuan Bank dalam memanfaatkan seluruh dana yang dimiliki untuk memperoleh laba maksimal dengan meningkatkan penjualan dan menekan beban atau biaya operasional. Earnings dapat diukur melalui BOPO, Return On Equity (ROE), Return On Assets (ROA), NIM (Net Interst Margin). Capital berfungsi untuk mengukur kemampuan bank dalam menyerap kerugian-kerugian yang tidak dapat dihindari lagi serta dapat pula digunakan untuk mengukur besar-kecilnya kekayaan bank tersebut atau kekayaan yang dimiliki oleh para pemegang sahamnya. Salah satu untuk mengukur capital adalah menggunakan Capital Adequacy Ratio (CAR). CAR adalah rasio kecukupan modal yang berfungsi menampung risiko kerugian yang mungkin dihadapi oleh Bank.

PT Bank Pembangun Daerah Sumsel yang merupakan badan hukum Bank Sumsel-Babel (sebelumnya adalah Bank SumSel) adalah bank daerah yang saham terbesarnya dimiliki oleh pemerintah daerah Sumatera Selatan dan Bangka Belitung. Bank Sumsel-Babel ini merupakan salah satu Bank Daerah paling berkembang di Indonesia, terbukti dengan banyaknya penghargaan dan penilaian baik dari berbagai lembaga. Beberapa produk dari Bank Sumsel-Babel antara lain produk investasi Depati, Tabungan Pesirah (Penggerak Potensi Daerah), pengiriman uang dengan Western Union, Kartu Debit, transaksi ekspor impor, layanan-layanan ATM seperti tarik tunai, pembelian pulsa, pembayaran tagihan listrik, dll. Bank SumSel-Babel saat ini memiliki kantor pusat di Palembang, seta dilengkapi dengan 18 Kantor Cabang, 31 Kantor Cabang Pembantu, 23 Kantor Kas yang tersebar di seluruh daerah provinsi Sumatera Selatan dan Bangka Belitung. Selain itu saat ini Bank Sumsel juga telah memiliki Unit Syariah, yang melayani produk perbankan syariah termasuk tabungan haji.

\section{B. KAJIAN TEORI}

1) Laporan Keuangan

\section{$>$ Pengertian Laporan Keungan}

Laporan keuangan merupakan laporan tertulis yang memberikan informasi kuantitatif tentang posisi keuangan dan perubahan-perubahannya, serta hasil yang dicapai selama periode tertentu. Laporan keuangan dapat dijadikan media yang dapat dipakai untuk meneliti kondisi kesehatan perusahaan, dimana laporan keuangan tersebut terdiri dari laporan posisi keuangan, perhitungan rugi laba komprehensif dan ikhtisar laba ditahan. sumber:

Berikut ini merupakan pengertian dan definisi laporan keuangan dari berbagai

1. Menurut Brigham (2013:84) "laporan keuangan adalah beberapa lembar kertas dengan angka-angka yang tertulis di atasnya, tetapi penting juga untuk memikirkan aset-aset nyata yang berada di balik angka tersebut."

2. Menurut Munawir (2010:2) Laporan keuangan pada dasarnya adalah hasil dari proses akuntansi yang dapat digunakan sebagai alat untuk berkomunikasi antara data keuangan atau aktivitas suatu perusahaan dengan pihak-pihak yang berkepentingan dengan data atau aktivitas perusahaan tersebut.

3. Menurut Harahap (2013:105) Laporan keuangan menggambarkan kondisi keuangan dan hasil usaha suatu perusahaan pada saat tertentu atau jangka waktu tertentu. 
4. Menurut Hery (2012:3) Laporan keuangan pada dasarnya adalah hasil dari proses akuntansi yang dapat digunakan sebagai alat untuk mengkomunikasikan data keuangan atau aktivitas perusahaan kepada pihakpihak yang berkepentingan.

5. Menurut Fahmi (2013:2) Laporan keuangan merupakan suatu informasi yang menggambarkan kondisi keuangan suatu perusahaan, dan lebih jauh informasi tersebut dapat dijadikan sebagai gambaran kinerja keuangan perusahaan tersebut.

Berdasarkan pengertian-pengertian di atas, dapat dikatakan bahwa laporan keuangan mencerminkan semua transaksi usaha sepanjang waktu yang menghasilkan baik peningkatan maupun penurunan bersih nilai ekonomi bagi pemilik modal. Oleh karena itu laporan keuangan merupakan media yang paling penting untuk menilai prestasi dan kondisi ekonomis suatu perusahaan.

\section{$>\quad$ Tujuan Laporan Keuangan}

Laporan keuangan disusun memiliki tujuan untuk menyediakan informasi keuangan mengenai suatu perusahaan kepada pihak-pihak yang berkepentingan sebagai pertimbangan dalam pembuatan keputusan-keputusan ekonomi.

Tujuan pembuatan atau penyusunan laporan keuangan menurut Kasmir (2014:10) adalah :

1) Memberikan informasi tentang jenis dan jumlah aset (harta) yang dimiliki perusahaan pada saat ini;

2) Memberikan informasi tentang jenis dan jumlah liabilitas dan ekuitas yang dimiliki perusahaan pada saat ini;

3) Memberikan informasi tentang jenis dan jumlah pendapatan yang diperoleh pada suatu periode tertentu;

4) Memberikan informasi tentang jumlah biaya dan jenis biaya yang dikeluarkan perusahaan dalam suatu periode tertentu;

5) Memberikan informasi tentang perubahan-perubahan yang terjadi terhadap aset, liabilitas, dan ekuitas perusahaan;

6) Memberikan informasi tentang kinerja manajemen perusahaan dalam suatu periode;

7) Memberikan informasi tentang catatan-catatan atas laporan keuangan;

8) Informasi keuangan lainnya.

Sedangkan menurut Harahap (2013:70) mengemukakan bahwa: "Tujuan laporan keuangan merupakan dasar awal dari struktur teori akuntansi".

Menurut Fahmi (2013:5) tujuan laporan keuangan adalah: "memberikan informasi kepada pihak yang membutuhkan tentang kondisi suatu perusahaan dari sudut angka-angka dalam satuan moneter".

\section{$>\quad$ Pemakai Laporan Keuangan}

Laporan keuangan merupakan komoditi yang bermanfaat dan dibutuhkan masyarakat, karena ia dapat memberikan informasi yang dibutuhkan pemakainya dalam dunia bisnis yang dapat menghasilkan keuntungan. Laporan keuangan disajikan kepada banyak pihak yang berkepentingan termasuk manajemen, kreditur, pemerintah dan pihak-pihak lainnya. Beberapa kebutuhan pemakai laporan keuangan meliputi (Standar Akuntansi Keuangan, 2010) : 
1. Investor. Penanam modal berisiko dan penasihat merekan berkepentingan dengan risiko yang melekat serta hasil pengembangan dari investasi yang mereka lakukan. Mereka membutuhkan informasi yang membantu menentukan apakah harus membeli, menahan, atau menjual investasi tersebut. Pemegang saham juga tertarik pada informasi yang memungkinkan mereka untuk menilai kemampuan perusahaan untuk membayar deviden.

2. Karyawan. Karyawan dan kelompok-kelompok yang mewakili mereka tertarik pada informasi mengenai stabilitas dan profitabilitas perusahaan. Mereka juga tertarik dengan informasi yang memungkinkan mereka untuk menilai kemampuan perusahaan dalam memberikan balas jasa, manfaat pensiun dan kesempatan kerja.

3. Pemberian pinjaman. Pemberian pinjaman tertarik dengan informasi keuangan yang memungkinkan mereka untuk memutuskan apakah pinjaman serta bunganya dapat dibayar pada satu jatuh tempo.

4. Pemasok dan kreditur usaha lainnya. Pemasok dan kreditur usaha lainnya tertarik dengan informasi keuangan yang memungkinkan mereka untuk memutuskan apakah jumlah yang terhutang akan dibayar pada saat jatuh tempo. Kreditur usaha berkepentingan pada prusahaan dalam tenggang waktu yang lebih pendek dari pada pemberi pinjaman kecuali kalau sebagai pelanggan utama mereka tergantung pada kelangsungan hidup perusahaan.

5. Pelanggan. Para pelanggan berkepentingan dengan informasi mengenai kelangsungan hidup perusahaan, terutama kalau mereka terlibat dalam perjanjian jangka panjang dengan, atau tergantung pada perusahaan.

6. Pemerintah. Pemerintah dengan berbagai lembaga yang berada dibawah kekuasaanya berkepentingan dengan alokasi sumber daya dan karena itu berkepentingan dengan aktivitas perusahaan. Mereka juga membutuhkan informasi untuk mengatur aktivitas perusahaan, menetapkan kebijakan pajak dan sebagai dasar untuk menyusun statistik pendapatan nasional dan statistik lainnya.

7. Masyarakat. Perusahaan mempengaruhi anggota masyarakat dengan berbagai cara misalnya: perusahaan dapat memberikan kontribusi berarti pada perekonomian nasional, termasuk jumlah orang yang dipekerjakan dan perlindungan kepada penanam modal domestik. Laporan keuangan dapat membantu masyarakat dengan menyediakan informasi kecendrungan (trend) dan perkembangn terakhir kemakmuran perusahaan serta rangkaian aktivitas.

\section{2) Analisis Laporan Keuangan}

\section{$>\quad$ Pengertian Analisis Laporan Keuangan}

Analisis laporan keuangan terdiri dari dua kata yaitu analisis dan laporan keuangan. Analisis adalah memecahkan atau menguraikan sesuatu unit menjadi berbagai unit terkecil. Laporan keuangan adalah posisi laporan keuangan, laporan laba-rugi, laporan aliran kas. Jadi analisis laporan keuangan sebagaimana dikemukakan oleh Maith dalam Harahap (2011:190), yaitu : "Analisis laporan keuangan adalah penguraian pos-pos laporan keuangan menjadi unit informasi yang lebih kecil dan melihat hubungannya yang bersifat signifikan atau mempunyai makna 
antara satu dengan yang lain baik antara data kuantitatif maupun data non kuantitatif dengan tujuan untuk mengetahui kondisi keuangan lebih dalam yang sangat penting dalam menghasilkan keputusan yang tepat".

Menurut Subramanyam (2014:4) Analisis laporan keuangan (financial statement analysis) adalah aplikasi dari alat dan teknik analitis untuk laporan keuangan bertujuan umum dan data-data yang berkaitan untuk menghasilkan estimasi dan kesimpulan yang bermanfaat dalam analisis bisnis. Analisis laporan keuangan mengurangi ketergantungan pada firasat, tebakan, dan intuisi dalam pengambilan keputusan, serta mengurangi ketidakpastian analisis bisnis.

Menurut Munawir (2010:31) Analisa laporan keuangan terdiri dari penelahaan atau mempelajari dari pada hubungan-hubungan atau kecenderungan untuk menentukan posisi keuangan dan operasi serta perkembangan usaha yang bersangkutan. Dengan diadakannya analisa laporan keuangan ini diharapkan dapat dihasilkan informasi yang berguna bagi pihak yang berpentingan.

\section{$>\quad$ Tujuan dan Manfaat Analisis Laporan Keuangan}

Sedangkan menurut Kasmir (2014: 68) ada 6 tujuan dan manfaat bagi berbagai pihak dengan adanya analisis laporan keuangan, yaitu :

1) Untuk mengetahui posisi keuangan perusahaan dalam satu periode tertentu, baik harta, kewajiban, modal, maupun hasil usaha yang telah dicapai untuk beberapa periode.

2) Untuk mengetahui kelemahan-kelemahan apa saja yang menjadi kekurangan perusahaan.

3) Untuk mengetahui kekuatan-kekuatan yang dimiliki.

4) Untuk mengetahui langkah-langkah perbaikan apa saja yang pelu dilakukan ke depan yang berkaitan dengan posisi keuangan perusahaan saat ini.

5) Untuk melakukan penilaian kinerja manajemen ke depan apakah perlu penyegaran atau tidak karena sudah dianggap berhasil atau gagal.

6) Dapat juga digunakan sebagai pembandingan dengan perusahaan sejenis tentang hasil yang mereka capai.

\section{$>\quad$ Metode dan Teknik Analisis Laporan Keuangan}

Menurut Munawir (2010:36), ada dua metode analisis yang digunakan oleh setiap penganalisis laporan keuangan, yaitu analisis horisontal dan analisis vertikal. Analisis horisontal adalah analisis dengan mengadakan perbandingan laporan keuangan untuk beberapa periode atau beberapa saat sehingga akan diketahui perkembangannya. Analisis vertikal adalah apabila laporan keuangan yang dianalisis hanya meliputi satu periode atau satu saat saja, yaitu dengan memperbandingkan antara akun yang satu dengan akun yang lain dalam laporan keuangan tersebut sehingga hanya akan diketahui keadaan keuangan atau hasil operasi pada saat itu saja.

Menurut Munawir (2010:36-37), teknik analisis laporan keuangan terdiri dari :

1) Analisis Perbandingan Laporan Keuangan, adalah metode dan teknik analisis dengan cara memperbandingkan laporan keuangan untuk dua periode atau lebih, dengan menunjukkan:
a. Data absolut atau jumlah-jumlah dalam rupiah.
b. Kenaikan atau penurunan dalam jumlah rupiah.
c. Kenaikan atau penurunan dalam persentase. 
d. Perbandingan yang dinyatakan dalam rasio.

e. Persentase dalam total.

Analisis dengan menggunakan metode ini akan dapat diketahui perubahanperubahan yang terjadi dan perubahan mana yang memerlukan penelitian lebih lanjut.

2) Trendatau tendensi atau posisi dan kemajuan keuangan perusahaan yang dinyatakan dalam persentase (Trend Percentage Analysis), adalah suatu metode atau teknik analisis untuk mengetahui tendensi daripada keadaan keuangannya, apakah menunjukkan tendensi tetap, naik atau bahkan turun.

3) Laporan dengan persentase per komponen (Common Size Statement), adalah suatu metode analisis untuk mengetahui persentase investasi pada masingmasing aset terhadap total asetnya, juga untuk mengetahui struktur permodalannya dan komposisi perongkosan yang terjadi dihubungkan dengan jumlah penjualannya.

4) Analisis Sumber dan Penggunaan Modal Kerja, adalah suatu analisis untuk mengetahui sumber-sumber serta penggunaan modal kerja atau untuk mengetahui sebab-sebab berubahnya modal kerja dalam periode tertentu.

5) Analisis Sumber dan Penggunaan Kas (Cash Flow Statement Analysis), adalah suatu analisis untuk mengetahui sebab-sebab berubahnya jumlah uang kas atau untuk mengetahui sumber-sumber serta penggunaan uang kas selama periode tertentu.

6) Analisis Rasio, adalah suatu metode analisis untuk mengetahui hubungan dari akun-akun tertentu dalam neraca atau laporan laba-rugi secara individu atau kombinasi dari kedua laporan tersebut.

7) Analisis Perubahan Laba Kotor (Gross Profit Analysis), adalah suatu analisis untuk mengetahui sebab-sebab perubahan laba kotor suatu perusahaan dari suatu periode ke periode yang lain atau perubahan laba kotor dari suatu periode dengan laba yang dibudgetkan untuk periode tersebut.

8) Analisis Break Even, adalah suatu analisis untuk menentukan tingkat penjualan yang harus dicapai oleh suatu perusahaan agar perusahaan tersebut tidak mengalami kerugian, tetapi juga belum memperoleh keuntungan. Dengan analisis ini juga akan diketahui berbagai tingkat keuntungan atau kerugian untuk berbagai tingkat penjualan.

Metode dan teknik analisis manapun yang digunakan, kesemuanya itu merupakan permulaan dari proses analisis yang diperlukan untuk menganalisis laporan keuangan, dan setiap metode analisis mempunyai tujuan yang sama yaitu untuk membuat agar data lebih dimengerti sehingga dapat digunakan sebagai dasar pengambilan keputusan bagi pihak-pihak yang membutuhkan.

\section{3) Analisis Rasio Keuangan}

\section{$>\quad$ Pengertian Analisis Rasio Keuangan}

Analisis laporan keuangan perusahan pada dasarnya merupakan perhitungan rasio-rasio untuk menilai keadaan keuangan perusahaan di masa lalu, saat ini, dan kemungkinan di masa yang akan datang.

Menurut Kasmir (2014:104), menjelaskan rasio keuangan merupakan kegiatan membandingkan angka-angka yang ada dalam laporan keuangan dengan cara membagi satu angka dengan angka yang lainnya. 
Menurut Munawir (2010:36) ada dua metode analisis yang digunakan oleh setiap penganalisa laporan keuangan, yaitu analisis horizontal dan analisis vertikal. Analisis horizontal adalah analisis dengan mengadakan pembandingan laporan keuangan untuk beberapa periode atau beberapa saat, sehingga akan diketahui perkembangannya. Metode horizontal ini disebut pula sebagai metode analisis dinamis. Analisis vertikal yaitu apabila laporan keuangan yang dianalisis hanya meliputi satu saat saja, yaitu dengan memperbandingkan antara pos yang satu dengan pos yang lainnya dalam laporan keuangan tersebut, sehingga hanya akan diketahui keadaan keuangan atau hasil operasi pada saat itu saja. Analisis vertikal ini disebut juga sebagai metode analisis yang statis karena kesimpulan yang dapat diperoleh hanya untuk periode itu saja tanpa mengetahui perkembangannya.

Sedangkan menurut Riyanto (2011:329), dalam mengadakan analisis rasio keuangan pada dasarnya dapat melakukannya dengan 2 macam cara pembandingan, yaitu :

a. Membandingkan rasio sekarang (present ratio) dengan rasio-rasio dari waktuwaktu yang lalu (rasio historis) atau dengan rasio-rasio yang diperkirakan untuk waktu-waktu yang akan datang dari perusahaan yang sama. Dengan cara pembanding ini akan dapat diketahui perubahan-perubahan dari rasio tersebut dari tahun ke tahun. Kalau diketahui perubahan dari angka rasio tersebut maka dapatlah diambil kesimpulan mengenai tendensi atau kecenderungan keadaan keuangan serta hasil operasi perusahaan yang bersangkutan.

b. Membandingkan rasio-rasio dari suatu perusahaan dengan rasio-rasio semacam dari perusahaan lain yang sejenis atau industri (rasio industri/rasio standar) untuk waktu yang sama. Dengan cara ini akan dapat diketahui apakah perusahaan yang bersangkutan dalam aspek keuangan tertentu berada di atas rata-rata industri, berada pada rata-rata atau terletak dibawah rata-rata industri.

Menurut Fahmi (2013:133), untuk dapat menginterpretasikan hasil perhitungan rasio, maka diperlukan adanya pembanding. Pada pokoknya ada dua cara yang dapat dilakukan dalam membandingkan rasio keuangan perusahaan, yaitu:

1. Cross sectional approach, merupakan suatu cara mengevaluasi dengan jalan membandingkan rasio-rasio antara perusahaan yang satu dengan perusahaan yang lainnya yang sejenis pada saat bersamaan.

2. Time series analysis, merupakan suatu cara dengan membandingkan rasio-rasio keuangan perusahaan dari satu periode ke periode lainnya. Pembanding antara rasio yang dicapai saat ini dengan rasio-rasio pada masa lalu akan memperhatikan apakah perusahaan mengalami kemajuan atau kemunduran.

\section{$>\quad$ Penilaian Tingkat Kesehatan Bank \& Jenis-jenis Rasio Keuangan Bank}

Berdasarkan peraturan Bank Indonesia Nomor 13/1/PBI/2011 untuk melakukan penilaian Tingkat Kesehatan Bank dengan menggunakan pendekatan berdasarkan Risiko (Risk-based Bank Rating). Dimana penilaian ini disebut dengan metode RGEC (Risk Profile, GCG, Earnings and Capital).

Dalam penulisan penelitian ini, penulis hanya memfokuskan pada risk profile, earnings dan capital.

\section{a) Risk profile}

Risk profile dapat diukur menggunakan rasio Loan to Deposit Ratio (LDR) dan Non Performing Loan (NPL). 
"LDR (Loan to Deposit Ratio) adalah salah satu ukuran likuid dari konsep persediaan yang berbentuk rasio pinjaman terhadap deposit." Darmawi (2011:61)

Agar definisi LDR menjadi lebih jelas, peneliti mengutip definisi yang dikemukakan oleh Kasmir (2014:225) "LDR (Loan to Deposit Ratio) adalah rasio yang digunakan untuk mengukur komposisi jumlah kredit yang diberikan dibandingkan dengan jumlah dana masyarakat dan modal sendiri yang digunakan."

Dari pengertian LDR menurut para ahli diatas, maka dapat disimpulkan bahwa LDR adalah rasio yang mengukur sejauh mana kemampuan bank dalam membayar kembali penarikan dana yang dilakukan deposan dengan mengandalkan kredit yang diberikan sebagai sumber likuiditasnya. Semakin tinggi rasio ini maka semakin rendahnya likuiditas bank yang bersangkutan. Namun sebaliknya, jika semakin rendah rasio LDR maka semakin tinggi likuiditas

bank yang bersangkutan. Rasio ini juga merupakan indikator kerawanan dan kemampuan dari suatu bank.

Menurut Kasmir (2014:225), batas aman dari LDR suatu bank adalah sekitar $80 \%$. Namun batas maksimal LDR adalah 110\%. Rasio LDR dihitung dengan membandingkan kredit dengan dana pihak ketiga dimana kredit yang digunakan merupakan total kredit yang diberikan kepada pihak ketiga, dan tidak termasuk kredit yang diberikan kepada pihak lain. Sedangkan dana pihak ketiga merupakan giro, tabungan, dan deposito yang tidak termasuk antarbank.

Menurut Peraturan BI No. 17/11/PBI/2015 rasio non performing loan (NPL) adalah rasio antara jumlah total kredit dengan kualitas kurang lancar, diragukan dan macet terhadap total kredit.

Menurut Kasmir (2010:112) mendefinisikan kredit bermasalah sebagai berikut “ Kredit bermasalah atau kredit macet adalah kredit yang didalamnya terdapat hambatan yang disebabkan oleh 2 unsur yakni dari pihak perbankan dalam menganalisis maupun dari pihak nasabah yang dengan sengaja atau tidak sengaja dalam kewajibannya tidak melakukan pembayaran."

\section{b) Earnings}

Menurut Bambang Riyanto (2011:59) bahwa: "Rentabilitas suatu perusahaan menunjukan perbandingan antara laba dengan aktiva atau modal yang menghasilkan laba tersebut."

Menurut Munawir (2010:33) bahwa: "Rentabilitas adalah kemampuan perusahaan menghasilkan laba selama periode tertentu."

Jadi dari berbagai pendapat diatas, dapat disimpulkan rentabilitas (earnings) adalah perbandingan antara laba dengan modal yang menghasilkan laba tersebut.

Berdasarkan peraturan Bank Indonesia Nomor 13/1/PBI/2011 rasio yang dapat mengukur rentabilitas bank antara lain BOPO, Return On Assets (ROA) dan Return On Equity (ROE) dan Net Inters Margin (NIM). Dalam rasio rentabilitas ini peneliti hanya menganalisa tiga rasio yaitu BOPO, ROA dan ROE.

BOPO menurut kamus keuangan adalah kelompok rasio yang mengukur efesiensi dan efektivitas operasional suatu perusahaan dengan jalur membandingkan satu terhadap lainnya. Semakin rendah BOPO berarti semakin efisien bank tersebut dalam mengendalikan biaya operasionalnya, dengan adanya efisiensi biaya maka keuntungan yang diperoleh bank akan semakin besar.

Return On Asset (ROA) menurut Kasmir (2014:201) adalah rasio yang menunjukan hasil (return) atas jumlah aktiva yang digunakan dalam perusahaan. Selain itu, ROA memberikan ukuran yang lebih baik atas profitabilitas perusahaan 
karena menunjukan efektivitas manajemen dlam menggunakan aset untuk mmemperoleh pendapatan. Menurut Harahap (2013:305) ROA menggambarkan perputaran aset diukur dari penjualan. Semakin besar rasio ini maka semakin baik dan hal ini berarti bahwa aset dapat lebih cepat berputar dan meraih laba.

Menurut Gitman (2012:82) bahwa "Return on common equity measure the return earned on the common stockholder's investment in the firm" artinya bahwa return on equity secara umum mengukur pengembalian yang diperoleh atas investasi pemegang saham biasa di perusahaan.

\section{c) Capital}

Salah satu komponen faktor permodalan Menurut Darmawi (2011:91) adalah kecukupan modal. Rasio untuk menguji kecukupan modal bank yaitu rasio CAR (Capital Adequacy Ratio). Agar definisi CAR menjadi lebih jelas, peneliti mengutip definisi yang dikemukakan beberapa ahli :

Menurut Kuncoro (2011:519) CAR adalah kecukupan modal yang menunjukkan bank dalam mempertahankan modal yang mencukupi dan kemampuan manajemen bank dalam mengidentifikasi, mengukur, mengawasi, dan mengontrol resiko-resiko yang timbul yang dapat berpengaruh terhadap besarnya modal bank.

Menurut Kasmir (2014:46), CAR adalah perbandingan rasio tersebut antara rasio modal terhadap Aset Tertimbang Menurut Resiko dan sesuai ketentuan pemerintah. Menurut Sudirman (2013:111), cara menghitung besarnya jumlah modal bank yaitu dengan cara menambahkan modal inti ditambah dengan modal pelengkap. Modal inti terdiri dari modal yang disetor oleh pemilik, sumbangan, agio saham, dana setoran modal, modal sumbangan, dan sebagainya. Sedangkan modal pelengkap hanya dapat diperhitungkan maksimum 100\% dari modal inti yang terdiri dari cadangan revaluasi aktiva tetap, penyisihan penghapusan Aktiva Produktif (PPAP), modal pinjaman, dan sebagainya. Kewajiban kebutuhan modal minimum dihitung dengan mengalikan ATMR dengan 8\%. Rasio modal dihitung dengan membandingkan modal minimum dengan ATMR.

Menurut Darmawi (2011:99), dengan kata lain yaitu CAR 8\% berarti jumlah capital adalah sebesar $8 \%$ dari ATMR, atau sebaliknya jumlah ATMR adalah sebesar 12,5 kali modal yang tersedia atau dimiliki bank yang bersangkutan. Semakin tinggi CAR semakin baik kinerja suatu bank. Besarnya modal suatu bank, akan mempengaruhi tingkat kepercayaan masyarakat terhadap kinerja bank.

\section{4) Kinerja Keuangan}

\section{$>$ Pengertian Kinerja Keuangan}

Kinerja keuangan merupakan gambaran pencapaian dari suatu perusahaan, kinerja keuangan dapat diperoleh dari informasi yang terdapat dari laporan keuangan. Pengertian kinerja keuangan menurut Rudianto (2013:189) yaitu "hasil dari suatu prestasi yang telah dicapai oleh manajemen perusahaan dalam menjalankan fungsinya mengelola aset perusahaan secara efektif selama periode tertentu".

Sedangkan menurut Irham Fahmi (2013:2) kinerja keuangan adalah "suatu analisis yang dilakukan untuk melihat sejauh mana perusahaan telah melaksanakan dengan menggunakan aturan-aturan pelaksanaan keuangan secara baik dan benar seperti dalam membuat suatu laporan keuangan yang telah memenuhi standar atau ketentuan dalam SAK (standar akuntansi keuangan) atau GAAP (generally accepted accounting princip/) dan lainnya". 
Kemudian menurut Jumingan (2011:239) kinerja keuangan yaitu "merupakan gambaran kondisi keuangan pada suatu periode tertentu baik menyangkut aspek penghimpunan dana maupun penyaluran dana yang biasanya diukur dengan indikator kecukupan modal, likuiditas dan profitabilitas".

Menurut pemaparan tersebut dpat ditarik kesimpulan bahwa kinerja keuangan adalah hasil atau prestasi suatu perusahaan yang dicapai dalam suatu periode atau beberapa periode tertentu dalam pengelolaan keuangan perusahaan, dengan prestasi perusahaan tersebut dapat menggambarkan kinerja perusahaan.

\section{$>\quad$ Pengukuran Kinerja Keuangan}

Kinerja keuangan perusahaan berkaitan erat dengan pengukuran dan penilaian kinerja. Pengukuran kinerja (performing measurement) adalah kualifikasi dan efisiensi serta efektivitas perusahaan dalam pengoperasian bisnis selama periode akuntansi.

Pengukuran kinerja digunakan perusahaan untuk melakukan perbaikan di atas kegiatan operasionalnya agar dapat bersaing dengan perusahaan lain. Analisis kinerja keuangan merupakan proses pengkajian secara kritis terhadap review data, menghitung, mengukur, menginterprestasi, dan memberi solusi terhadap keuangan perusahaan pada suatu periode tertentu.

Menurut Munawir (2012:31) menyatakan bahwa tujuan dari pengukuran kinerja keuangan perusahaan adalah:

\section{Mengetahui Tingkat Likuiditas.}

Likuiditas menunjukkan kemampuan suatu perusahaan untuk memenuhi kewajiban keuangan yang harus segera diselesaikan pada saat ditagih.

\section{Mengetahui Tingkat Solvabilitas.}

Solvabilitas menunjukkan kemampuan perusahaan untuk memenuhi kewajiban keuangannya apabila perusahaan tersebut dilikuidasi, baik keuangan jangka pendek maupun jangka panjang.

\section{Mengetahui Tingkat Rentabilitas.}

Rentabilitas atau yang sering disebut dengan profitabilitas menunjukkan kemampuan perusahaan untuk menghasilkan laba selama periode tertentu.

\section{Mengetahui Tingkat Stabilitas.}

Stabilitas menunjukkan kemampuan perusahaan untuk melakukan usahanya dengan stabil, yang diukur dengan mempertimbangkan kemampuan perusahaan untuk membayar hutang-hutangnya serta membayar beban bunga atas hutang-hutangnya tepat pada waktunya.

\section{METODE PENELITIAN}

Metode penelitian pada dasarnya merupakan cara ilmiah untuk mendapatkan data dengan tujuan dan kegunaan tertentu. Data yang diperoleh melalui penelitian itu adalah data empiris (teramati) yang mempunyai kriteria tertentu yaitu valid (Sugiono,2013:1). Valid yaitu menujukan derajat ketepatan antara data yang sesungguhnya terjadi pada obyek dengan data yang dapat dikumpulkan oleh peneliti.

Berdasarkan kerangka teori yang dipaparkan diatas, penelitian ini menggunakan metode kuantitatif. Menurut Sugiyono (2012:7) metode kuantitatif dinamakan metode tradisional, karena metode ini sudah cukup lama digunakan sehingga sudah mentradisi sebagai metode untuk penelitian. Metode ini disebut sebagai metode positivistik karena berlandaskan pada filsafat positivisme. Metode ini 
sebagai metode ilmiah/scientific karena telah memenuhi kaidah-kaidah ilmiah yaitu konkrit/empiris, obyektif, terukur, rasional, dan sistematis. Metode ini juga disebut metode discovery, karena dengan metode ini dapat ditemukan dan dikembangkan sebagai iptek baru. Metode ini disebut metode kuantitatif karena data penelitiannya berupa angka-angka.

\section{1) Populasi dan Sampel \\ a) Populasi}

Menurut Sugiyono (2012:117) populasi adalah wilayah generalisasi yang terdiri atas obyek/subyek yang mempunyai kualitas dan karakteristik tertentu yang ditetapkan oleh peneliti untuk dipelajari dan kemudian ditarik kesimpulannya. Jadi populasi bukan hanya orang, tetapi juga obyek dan benda-benda alam yang lain.

Menurut Hartono (2011: 46), populasi dengan karakteristik tertentu ada yang jumlahnya terhingga dan ada yang tidak terhingga. Penelitian hanya dapat dilakukan pada populasi yang jumlahnya terhingga saja.

Berdasarkan uraian diatas, populasi yang digunakan dalam penelitian ini adalah Laporan Keuangan PT. Bank Pembangunan Daerah Sumatera Selatan dan Bangka Belitung.

\section{b) Sampel}

Menurut Sugiyono (2012:118) sampel adalah bagian dari jumlah dan karakteristik yang dimiliki oleh populasi tersebut. Apabila peneliti melakukan penelitian terhadap populasi yang besar, sementara peneliti ingin meneliti tentang populasi tersebut dan peneliti memiliki keterbatasan dana, tenaga dan waktu, maka peneliti menggunakan teknik pengambilan sampel. Maknanya sampel yang diambil dapat mewakili atau representatif bagi populasi tersebut.

Berdasarkan pemaparan dari beberapa ahli diatas, sampel yang diambil pada penelitian ini adalah Laporan Posisi Keuangan dan Laporan Laba Rugi pada PT. Bank Pembangunan Daerah Sumatera Selatan dan Bangka Belitung dalam kurun waktu 2011-2015.

\section{2) Jenis dan Sumber Data $>\quad$ Jenis Data}

Sugiyono (2012:7) metode kuantitatif dinamakan metode tradisional, karena metode ini sudah cukup lama digunakan sehingga sudah mentradisi sebagai metode untuk penelitian. Metode ini disebut sebagai metode positivistik karena berlandaskan pada filsafat positivisme. Metode ini sebagai metode ilmiah/scientific karena telah memenuhi kaidah-kaidah ilmiah yaitu konkrit/empiris, obyektif, terukur, rasional, dan sistematis. Metode ini juga disebut metode discovery, karena dengan metode ini dapat ditemukan dan dikembangkan sebagai iptek baru. Metode ini disebut metode kuantitatif karena data penelitiannya berupa angka-angka.

Berdasarkan teori tersebut diatas, maka penelitian ini merupakan penelitian deskriptif kuantitatif, data yang diperoleh dari sampel populasi penelitian dianalisis sesuai dengan metode yang digunakan kemudian diinterprestasikan.

\section{$>\quad$ Sumber Data}

Penelitian ini menggunakan data sekunder. Pengertian dari data sekunder menurut Sugiyono (2012:137) adalah "Sumber data yang tidak langsung memberikan data kepada pengumpul data, misalnya lewat orang lain atau lewat 
dokumen". Data sekunder antara lain disajikan dalam bentuk data-data, dokumen, tabel-tabel mengenai topik penelitian. Penelitian mengumpulkan data penelitian melalui website PT. Bank Pembangunanan Daerah Sumatera Selatan dan Bangka Belitung yaitu www.banksumselbabel.com dengan mengunduh laporan keuangan tahun 2011-2015.

\section{3) Teknik Pengumpulan Data}

Sesuai dengan prosedur penulisan ilmiah pada umumnya, maka teknik pengumpulan data dalam penelitian ini diperoleh dengan dokumentasi. Menurut Sugiyono (2013:240) dokumen merupakan catatan peristiwa yang sudah berlalu. Dokumen bisa berbentuk tulisan, gambar, atau karya-karya monumental dari seseorang. Dokumen yang berbentuk tulisan misalnya catatan harian, sejarah kehidupan (life histories), ceritera, biografi, peraturan, kebijakan. Dokumen yang berbentuk gambar misalnya foto, gambar hidup, sketsa dan lain-lain. Dokumen yang berbentuk karya misalnya karya seni, yang dapat berupa gambar, patung, film dan lain-lain. Studi dokumen merupakan pelengkap dari penggunaan metode observasi dan wawancara dalam penelitian kualitatif.

\section{4) Teknik Analisis Data}

Dalam penelitian ini penulis menggunakan metode analisis deskriptif kuantitatif, dengan menggunakan analisis deskriptif kuantitatif penulis dapat memberikan penjelasan secara rinci mengenai analisis rasio keuangan perusahaan pada tahun 2011-2015 dan bagaimana kondisi keuangan perusahaan tersebut.

Dalam menganalisis rasio perusahaan, penulis menggunakan enam macam rasio keuangan yaitu rasio LDR (loan to deposit ratio), NPL(non performing loan), BOPO, ROA (return on assets), ROE (return on equity) dan CAR (capital adequacy Ratio).

\section{HASIL PENELITIAN}

\section{Risk Profile}

Berdasarkan Peraturan Bank Indonesia Nomor 13/1/PBI/2011, risk profile menggunakan perhitungan LDR (Loan To Deposit Ratio) dan NPL (Non Performing Loan).

a) LDR (Loan To Deposit Ratio)

Berikut ini adalah hasil analisis nilai Loan To Deposit Ratio (LDR) pada tahun 2011-2015 :

$>$ Tahun 2011

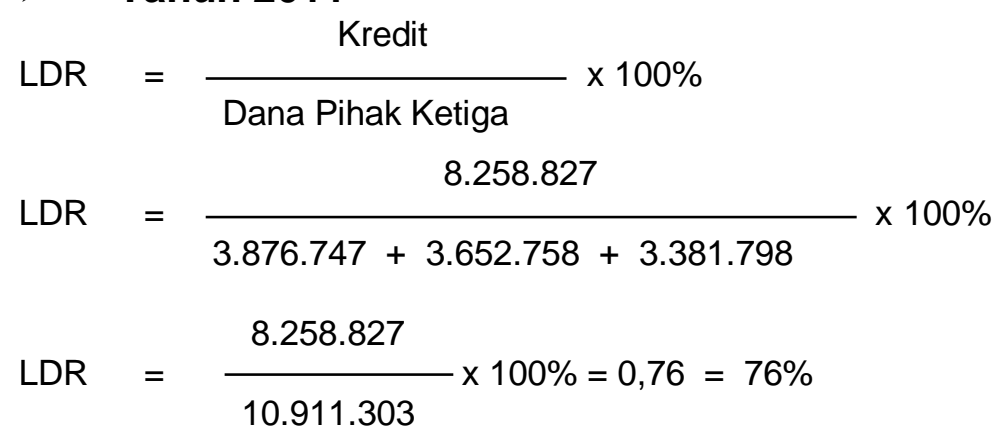

Berdasarkan hasil perhitungan Loan To Deposit Ratio (LDR) pada tahun 2011, rasio Loan To Deposit Rasio (LDR) yang dicapai Bank Sumsel Babel sebesar 76\% yang 
berarti setiap $100 \%$ dari dana yang diterima dari pihak ketiga maka kredit yang diberikan sebesar $76 \%$.

$>\quad$ Tahun 2012

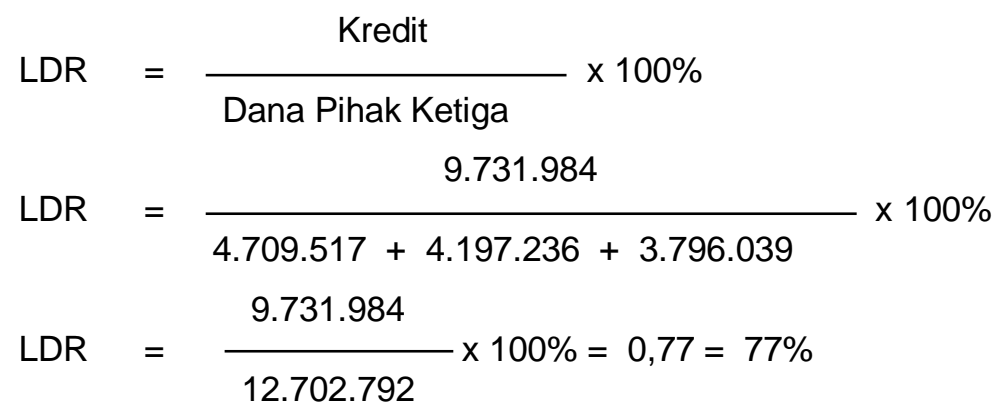

Berdasarkan hasil perhitungan Loan To Deposit Ratio (LDR) pada tahun 2012, rasio Loan To Deposit Rasio (LDR) yang dicapai Bank Sumsel Babel sebesar 77\% yang berarti setiap 100\% dari dana yang diterima dari pihak ketiga maka kredit yang diberikan sebesar $77 \%$.

$>$ Tahun 2013

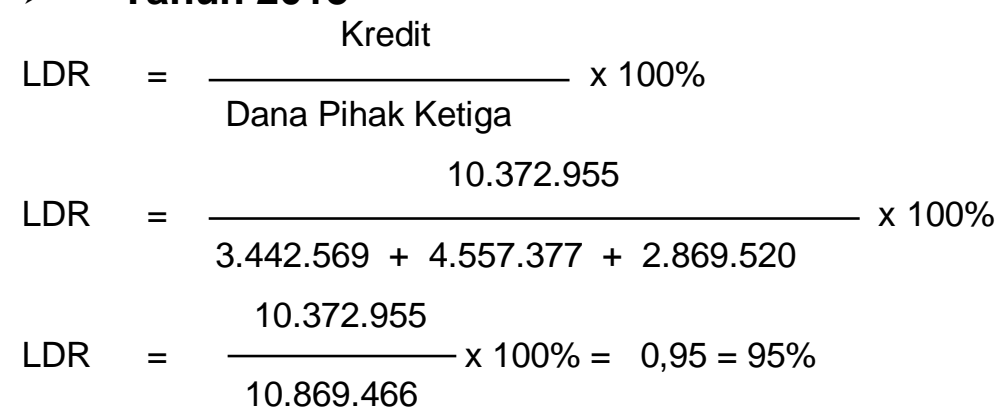

Berdasarkan hasil perhitungan Loan To Deposit Ratio (LDR) pada tahun 2013, rasio Loan To Deposit Rasio (LDR) yang dicapai Bank Sumsel Babel sebesar 95\% yang berarti setiap 100\% dari dana yang diterima dari pihak ketiga maka kredit yang diberikan sebesar $95 \%$.

$>$ Tahun 2014

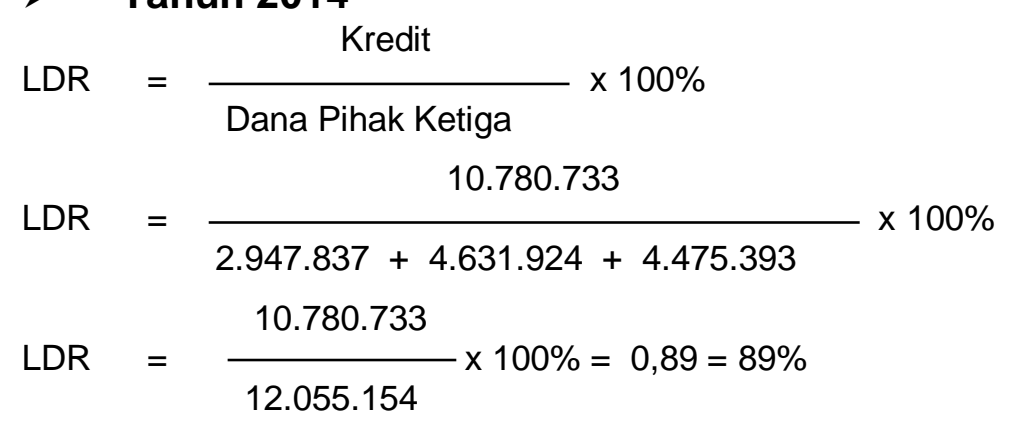

Berdasarkan hasil perhitungan Loan To Deposit Ratio (LDR) pada tahun 2014, rasio Loan To Deposit Rasio (LDR) yang dicapai Bank Sumsel Babel sebesar 89\% yang berarti setiap $100 \%$ dari dana yang diterima dari pihak ketiga maka kredit yang diberikan sebesar $89 \%$.

$>$ Tahun 2015

LDR $=\frac{\text { Kredit }}{\text { Dana Pihak Ketiga }} \times 100 \%$ 


$\begin{aligned} L D R & =\frac{11.499 .235}{1.958 .251+4.987 .033+4.412 .735} \times 100 \% \\ L D R & =\frac{11.499 .235}{11.358 .019} \times 100 \%=101=101 \%\end{aligned}$

Tabel Hasil Perhitungan Loan To Deposit Ratio (LDR) Bank Sumsel Babel Tahun 2011-2015

\begin{tabular}{|c|c|c|}
\hline No & Tahun & $\begin{array}{c}\text { Loan To Deposit Ratio } \\
\text { (LDR) }\end{array}$ \\
\hline 1. & 2011 & $76 \%$ \\
\hline 2. & 2012 & $77 \%$ \\
\hline 3. & 2013 & $95 \%$ \\
\hline 4. & 2014 & $89 \%$ \\
\hline 5. & 2015 & $101 \%$ \\
\hline
\end{tabular}

Sumber : Data diolah 2017

\section{b) NPL (Non Performing Loan)}

Berikut ini adalah hasil analisis nilai Non Performing Loan (NPL) pada tahun 2011-2015:

\section{$>\quad$ Tahun 2011}

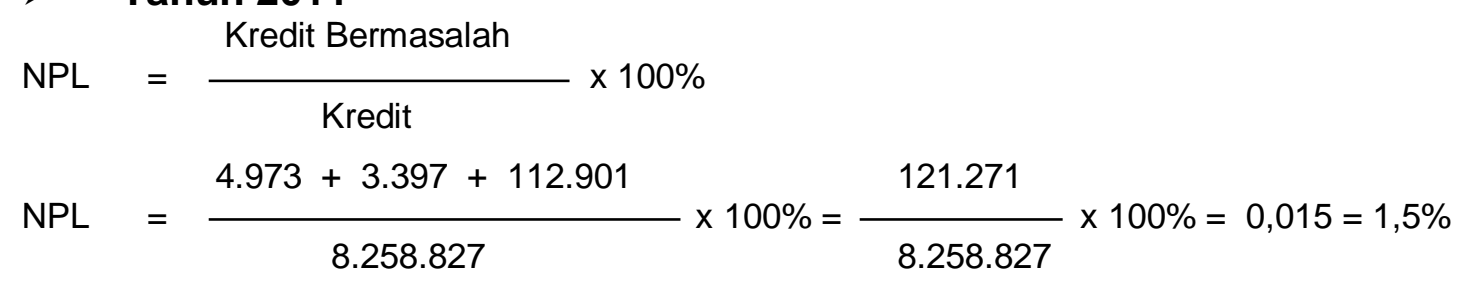

Berdasarkan hasil perhitungan Non Performing Loan (NPL) pada tahun 2011, rasio Non Performing Loan (NPL) yang dicapai Bank Sumsel Babel sebesar 1,5\% yang berarti setiap kredit yang diberikan sebesar $100 \%$ maka kredit yang bermasalah sebesar $1,5 \%$.

$>$ Tahun 2012

$$
\begin{aligned}
\text { NPL } & =\frac{\text { Kredit Bermasalah }}{\text { Kredit }} \times 100 \% \\
\mathrm{NPL} & =\frac{384.097+158.981+126.091}{9.731 .984} \times 100 \%=\frac{669.169}{9.731 .984} \times 100 \%=0,069=6,9 \%
\end{aligned}
$$

Berdasarkan hasil perhitungan Non Performing Loan (NPL) pada tahun 2012, rasio Non Performing Loan (NPL) yang dicapai Bank Sumsel Babel sebesar 6,9\% yang berarti setiap kredit yang diberikan sebesar $100 \%$ maka kredit yang bermasalah sebesar 6,9\% .

\section{$>$ Tahun 2013}

$$
\begin{aligned}
\text { NPL } & =\frac{\text { Kredit Bermasalah }}{\text { Kredit }} \times 100 \% \\
\mathrm{NPL} & =\frac{324.232+217.861+399.637}{10.372 .955} \times 100 \%=\frac{941.730}{10.372 .955} \times 100 \%=0,090=9 \%
\end{aligned}
$$


Berdasarkan hasil perhitungan Non Performing Loan (NPL) pada tahun 2013, rasio Non Performing Loan (NPL) yang dicapai Bank Sumsel Babel sebesar $9 \%$ yang berarti setiap kredit yang diberikan sebesar $100 \%$ maka kredit yang bermasalah sebesar $9 \%$.

$>\quad$ Tahun 2014

$\begin{aligned} \text { NPL } & =\frac{\text { Kredit Bermasalah }}{\text { Kredit }} \times 100 \% \\ N P L & =\frac{81.758+37.310+650.138}{10.055 .154} \times 100 \%=\frac{769.206}{10.055 .154} \times 100 \%=0,076=7,6 \%\end{aligned}$

Berdasarkan hasil perhitungan Non Performing Loan (NPL) pada tahun 2014, rasio Non Performing Loan (NPL) yang dicapai Bank Sumsel Babel sebesar 7,6\% yang berarti setiap kredit yang diberikan sebesar $100 \%$ maka kredit yang bermasalah sebesar 7,6\% .

\section{$>\quad$ Tahun 2015}

$\begin{aligned} \mathrm{NPL} & =\frac{\text { Kredit Bermasalah }}{\text { Kredit }} \times 100 \% \\ \mathrm{NPL} & =\frac{44.325+33.489+428.843}{11.499 .235} \times 100 \%=\frac{506.657}{11.499 .235} \times 100 \%=0,044=4,4 \%\end{aligned}$

Berdasarkan hasil perhitungan Non Performing Loan (NPL) pada tahun 2015, rasio Non Performing Loan (NPL) yang dicapai Bank Sumsel Babel sebesar 4,4\% yang berarti setiap kredit yang diberikan sebesar 100\% maka kredit yang bermasalah sebesar $4,4 \%$.

\section{Tabel Hasil Perhitungan Non Performing Loan (NPL)}

Bank Sumsel Babel Tahun 2011-2015

\begin{tabular}{|c|c|c|}
\hline No & Tahun & $\begin{array}{c}\text { Non Performing Loan } \\
\text { (NPL) }\end{array}$ \\
\hline 1. & 2011 & $1,5 \%$ \\
\hline 2. & 2012 & $6,9 \%$ \\
\hline 3. & 2013 & $9 \%$ \\
\hline 4. & 2014 & $7,6 \%$ \\
\hline 5. & 2015 & $4,4 \%$ \\
\hline
\end{tabular}

Sumber : Data diolah 2017

\section{Earnings}

Berdasarkan Peraturan Bank Indonesia Nomor 13/1/PBI/2011, earnings menggunakan perhitungan BOPO, ROA (Return On Assets) dan ROE (Return On Equity).

a) BOPO (Beban Operasional Pendapatan Operasional)

Berikut ini adalah hasil analisis nilai BOPO (Biaya Operasional Pendapatan Operasional) pada tahun 2011-2015 :

$>\quad$ Tahun 2011

$$
\text { BOPO }=\frac{\text { Beban Operasional }}{\text { Pendapatan Operasional }} \times 100 \%
$$




$$
\mathrm{BOPO}=\frac{632.284+871.896}{1.561 .896+303.498} \times 100 \%=\frac{1.504 .180}{1.865 .394} \times 100 \%=0,81=81 \%
$$

Berdasarkan hasil perhitungan BOPO (Biaya Operasional Pendapatan Operasional) pada tahun 2011, rasio BOPO yang dicapai Bank Sumsel Babel sebesar $81 \%$ yang berarti setiap kenaikan pendapatan operasional sebesar $100 \%$ maka biaya operasional sebesar $81 \%$.

$>\quad$ Tahun 2012

$$
\begin{aligned}
& \text { BOPO }=\frac{\text { Beban Operasional }}{\text { Pendapatan Operasional }} \times 100 \% \\
& \mathrm{BOPO}=\frac{532.366+1.151 .466}{1.644 .110+360.576} \times 100 \% \\
& \mathrm{BOPO}=\frac{1.683 .832}{2.004 .686} \times 100 \%=0,84=84 \%
\end{aligned}
$$

Berdasarkan hasil perhitungan BOPO (Biaya Operasional Pendapatan Operasional) pada tahun 2012, rasio BOPO yang dicapai Bank Sumsel Babel sebesar $84 \%$ yang berarti setiap kenaikan pendapatan operasional sebesar $100 \%$ maka biaya operasional sebesar $84 \%$.

$>\quad$ Tahun 2013

$$
\begin{aligned}
& \mathrm{BOPO}=\frac{\text { Beban Operasional }}{\text { Pendapatan Operasional }} \times 100 \% \\
& \mathrm{BOPO}=\frac{436.588+1.162 .630}{1.731 .730+122.933} \times 100 \%=\frac{1.599 .218}{1.854 .663} \times 100 \%=0,86=86 \%
\end{aligned}
$$

Berdasarkan hasil perhitungan BOPO (Biaya Operasional Pendapatan Operasional) pada tahun 2013, rasio BOPO yang dicapai Bank Sumsel Babel sebesar $86 \%$ yang berarti setiap kenaikan pendapatan operasional sebesar $100 \%$ maka biaya operasional sebesar $86 \%$.

\section{$>\quad$ Tahun 2014}

$$
\begin{aligned}
\text { BOPO } & =\frac{\text { Beban Operasional }}{\text { Pendapatan Operasional }} \times 100 \% \\
\text { BOPO } & =\frac{605.252+961.459}{1.795 .368+125.969} \times 100 \%=\frac{1.566 .711}{1.921 .337} \times 100 \%=0,82=82 \%
\end{aligned}
$$

Berdasarkan hasil perhitungan BOPO (Biaya Operasional Pendapatan Operasional) pada tahun 2014, rasio BOPO yang dicapai Bank Sumsel Babel sebesar $82 \%$ yang berarti setiap kenaikan pendapatan operasional sebesar $100 \%$ maka biaya operasional sebesar $82 \%$. 


\section{$>\quad$ Tahun 2015}

$$
\begin{aligned}
\mathrm{BOPO} & =\frac{\text { Beban Operasional }}{\text { Pendapatan Operasional }} \times 100 \% \\
\mathrm{BOPO} & =\frac{741.867+975.477}{1.974 .093+134.668} \times 100 \%=\frac{1.717 .344}{2.108 .761} \times 100 \%=0,81=81 \%
\end{aligned}
$$

Berdasarkan hasil perhitungan BOPO (Biaya Operasional Pendapatan Operasional) pada tahun 2011, rasio BOPO yang dicapai Bank Sumsel Babel sebesar $81 \%$ yang berarti setiap kenaikan pendapatan operasional sebesar $100 \%$ maka biaya operasional sebesar $81 \%$.

Tabel Hasil Perhitungan BOPO
(Beban Operasional Pendapatan Operasional)
Bank Sumsel Babel Tahun 2011-2015
\begin{tabular}{|c|c|c|}
\hline No & Tahun & BOPO \\
\hline 1. & 2011 & $81 \%$ \\
\hline 2. & 2012 & $84 \%$ \\
\hline 3. & 2013 & $86 \%$ \\
\hline 4. & 2014 & $82 \%$ \\
\hline 5. & 2015 & $81 \%$ \\
\hline
\end{tabular}

Sumber : Data diolah 2017

\section{b) ROA (Return On Assets)}

Berikut ini adalah hasil analisis nilai ROA pada tahun 2011-2015 :

$>\quad$ Tahun 2011

$\mathrm{ROA}=\frac{\text { Laba Sebelum Pajak }}{\text { Rata-rata Total Aset }} \times 100 \%=\frac{339.065}{12.001 .448} \times 100 \%=0.02=2 \%$

Berdasarkan hasil perhitungan ROA (Return On Assets) pada tahun 2011, rasio ROA (Return On Assets) yang dicapai Bank Sumsel Babel sebesar 2\% yang berarti setiap $100 \%$ dari aset akan menghasilkan laba sebelum pajak sebesar $2 \%$.

\section{$>$ Tahun 2012}

$\mathrm{ROA}=\frac{\text { Laba Sebelum Pajak }}{\text { Rata-rata Total Aset }} \times 100 \%=\frac{291.868}{14.467 .507} \times 100 \%=0,02=2 \%$

Berdasarkan hasil perhitungan ROA (Return On Assets) pada tahun 2012, rasio ROA (Return On Assets) yang dicapai Bank Sumsel Babel sebesar 2\% yang berarti setiap $100 \%$ dari aset akan menghasilkan laba sebelum pajak sebesar $2 \%$.

$>$ Tahun 2013

ROA $=\frac{\text { Laba Sebelum Pajak }}{\text { Rata-rata Total Aset }} \times 100 \%=\frac{277.858}{14.981 .411} \times 100 \%=0,02=2 \%$

Berdasarkan hasil perhitungan ROA (Return On Assets) pada tahun 2013, rasio ROA (Return On Assets) yang dicapai Bank Sumsel Babel sebesar $2 \%$ yang berarti setiap $100 \%$ dari aset akan menghasilkan laba sebelum pajak sebesar $2 \%$. 


\section{$>\quad$ Tahun 2014}

ROA $=\frac{\text { Laba Sebelum Pajak }}{\text { Rata-rata Total Aset }} \times 100 \%=\frac{347.650}{15.141 .419} \times 100 \%=0,02=2 \%$

Berdasarkan hasil perhitungan ROA (Return On Assets) pada tahun 2014, rasio ROA (Return On Assets) yang dicapai Bank Sumsel Babel sebesar 2\% yang berarti setiap $100 \%$ dari aset akan menghasilkan laba sebelum pajak sebesar $2 \%$.

$>\quad$ Tahun 2015

$\mathrm{ROA}=\frac{\text { Laba Sebelum Pajak }}{\text { Rata-rata Total Aset }} \times 100 \%=\frac{413.549}{16.288 .472} \times 100 \%=0,03=3 \%$

Berdasarkan hasil perhitungan ROA (Return On Assets) pada tahun 2015, rasio ROA (Return On Assets) yang dicapai Bank Sumsel Babel sebesar 3\% yang berarti setiap $100 \%$ dari aset akan menghasilkan laba sebelum pajak sebesar $3 \%$.

\section{Tabel Hasil Perhitungan ROA (Return On Assets)}

Bank Sumsel Babel Tahun 2011-2015

\begin{tabular}{|c|c|c|}
\hline No & Tahun & ROA (Return On Assets) \\
\hline 1. & 2011 & $2 \%$ \\
\hline 2. & 2012 & $2 \%$ \\
\hline 3. & 2013 & $2 \%$ \\
\hline 4. & 2014 & $2 \%$ \\
\hline 5. & 2015 & $3 \%$ \\
\hline
\end{tabular}

Sumber : Data diolah 2017

\section{c) ROE (Return On Equity)}

Berikut ini adalah hasil analisis nilai ROE pada tahun 2011-2015 :

\section{$>\quad$ Tahun 2011}

ROE $=\frac{\text { Laba Setelah Pajak }}{\text { Rata-rata Moal Inti }} \times 100 \%=\frac{246.796}{926.810} \times 100 \%=0,26=26 \%$

Berdasarkan hasil perhitungan ROE (Return On Equity) pada tahun 2011, rasio ROE (Return On Equity) yang dicapai Bank Sumsel Babel sebesar 26\% yang berarti setiap $100 \%$ dari modal inti akan menghasilkan laba setelah pajak sebesar $26 \%$.

$>$ Tahun 2012

ROE $=\frac{\text { Laba Setelah Pajak }}{\text { Rata-rata Moal Inti }} \times 100 \%=\frac{208.148}{1.150 .227} \times 100 \%=0,18=18 \%$

Berdasarkan hasil perhitungan ROE (Return On Equity) pada tahun 2012, rasio ROE (Return On Equity) yang dicapai Bank Sumsel Babel sebesar 18\% yang berarti setiap $100 \%$ dari modal inti akan menghasilkan laba setelah pajak sebesar $18 \%$.

$>\quad$ Tahun 2013

ROE $=\frac{\text { Laba Setelah Pajak }}{\text { Rata-rata Moal Inti }} \times 100 \%=\frac{174.929}{1.380 .745} \times 100 \%=0,13=13 \%$ 
Berdasarkan hasil perhitungan ROE (Return On Equity) pada tahun 2013, rasio ROE (Return On Equity) yang dicapai Bank Sumsel Babel sebesar 13\% yang berarti setiap $100 \%$ dari modal inti akan menghasilkan laba setelah pajak sebesar $13 \%$.

$>$ Tahun 2014

ROE $=\frac{\text { Laba Setelah Pajak }}{\text { Rata-rata Moal Inti }} \times 100 \%=\frac{250.695}{1.549 .491} \times 100 \%=0,16=16 \%$

Berdasarkan hasil perhitungan ROE (Return On Equity) pada tahun 2014, rasio ROE (Return On Equity) yang dicapai Bank Sumsel Babel sebesar 16\% yang berarti setiap $100 \%$ dari modal inti akan menghasilkan laba setelah pajak sebesar $16 \%$.

$>$ Tahun 2015

ROE $=\frac{\text { Laba Setelah Pajak }}{\text { Rata-rata Moal Inti }} \times 100 \%=\frac{282.584}{1.622 .046} \times 100 \%=0,17=17 \%$

Berdasarkan hasil perhitungan ROE (Return On Equity) pada tahun 2015, rasio ROE (Return On Equity) yang dicapai Bank Sumsel Babel sebesar 17\% yang berarti setiap $100 \%$ dari modal inti akan menghasilkan laba setelah pajak sebesar $17 \%$.

Tabel Hasil Perhitungan ROE (Return On Equity)
Bank Sumsel Babel Tahun 2011-2015
\begin{tabular}{|c|c|c|}
\hline No & Tahun & ROE (Return On Equity) \\
\hline 1. & 2011 & $26 \%$ \\
\hline 2. & 2012 & $18 \%$ \\
\hline 3. & 2013 & $13 \%$ \\
\hline 4. & 2014 & $16 \%$ \\
\hline 5. & 2015 & $17 \%$ \\
\hline
\end{tabular}
Sumber : Data diolah 2017

\section{Capital}

Berdasarkan Peraturan Bank Indonesia Nomor 13/1/PBI/2011, rasio kecukupan modal menggunakan perhitungan CAR (Capital Adequacy Ratio).

\section{A. CAR (Capital Adequacy Ratio)}

Berikut ini adalah hasil analisis nilai CAR pada tahun 2011-2015 :

$>$ Tahun 2011

$$
\begin{aligned}
\mathrm{CAR} & =\frac{\text { Modal }}{\text { Aset Tertimbang Menurut Resiko }} \times 100 \% \\
\mathrm{CAR} & =\frac{1.152 .876}{9.331 .957} \times 100 \%=0,12=12 \%
\end{aligned}
$$

Berdasarkan hasil perhitungan CAR (Capital Adequacy Ratio) pada tahun 2011, rasio CAR (Capital Adequacy Ratio) yang dicapai Bank Sumsel Babel sebesar 12\% yang berarti Bank Sumsel Babel pada tahun 2011 menyediakan 12\% dari investasinya untuk setiap aset tertimbang menurut resiko (ATMR) sejumlah $100 \%$ maka Bank Sumsel Babel membiayai dengan modal sebesar $12 \%$. 


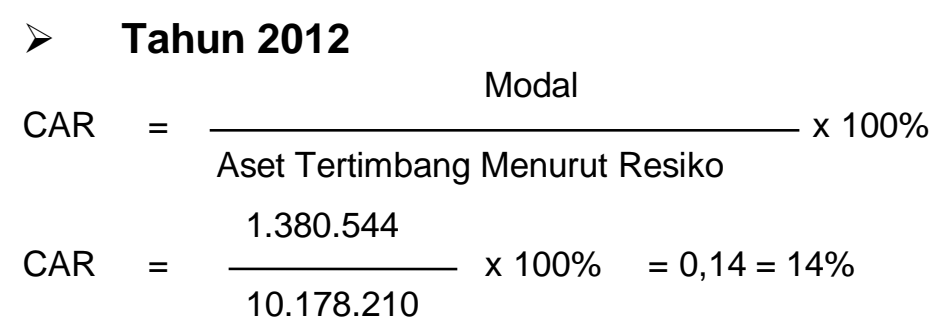

Berdasarkan hasil perhitungan CAR (Capital Adequacy Ratio) pada tahun 2012, rasio CAR (Capital Adequacy Ratio) yang dicapai Bank Sumsel Babel sebesar 14\% yang berarti Bank Sumsel Babel pada tahun 2012 menyediakan 14\% dari investasinya untuk setiap aset tertimbang menurut resiko (ATMR) sejumlah $100 \%$ maka Bank Sumsel Babel membiayai dengan modal sebesar $14 \%$.

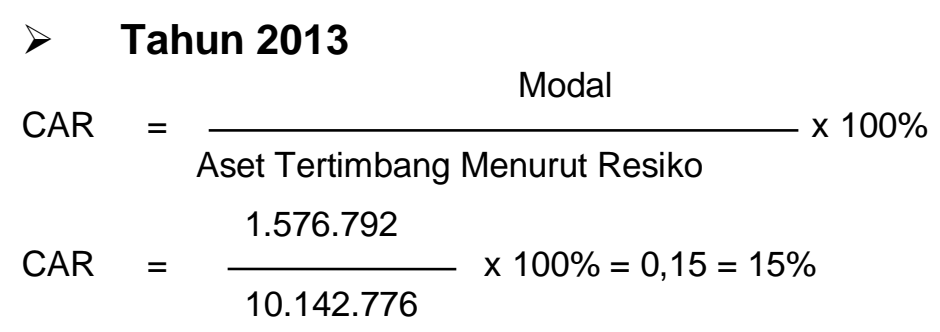

Berdasarkan hasil perhitungan CAR (Capital Adequacy Ratio) pada tahun 2013, rasio CAR (Capital Adequacy Ratio) yang dicapai Bank Sumsel Babel sebesar 15\% yang berarti Bank Sumsel Babel pada tahun 2013 menyediakan 15\% dari investasinya untuk setiap aset tertimbang menurut resiko (ATMR) sejumlah $100 \%$ maka Bank Sumsel Babel membiayai dengan modal sebesar 15\%.

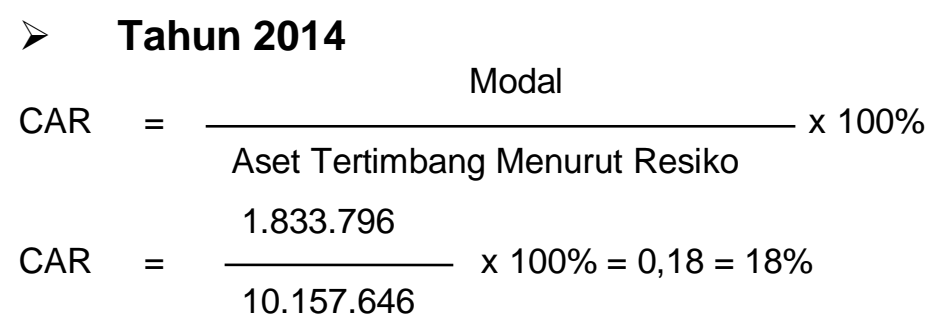

Berdasarkan hasil perhitungan CAR (Capital Adequacy Ratio) pada tahun 2014, rasio CAR (Capital Adequacy Ratio) yang dicapai Bank Sumsel Babel sebesar 18\% yang berarti Bank Sumsel Babel pada tahun 2014 menyediakan 18\% dari investasinya untuk setiap aset tertimbang menurut resiko (ATMR) sejumlah $100 \%$ maka Bank Sumsel Babel membiayai dengan modal sebesar 18\%.

\section{$>$ Tahun 2015}

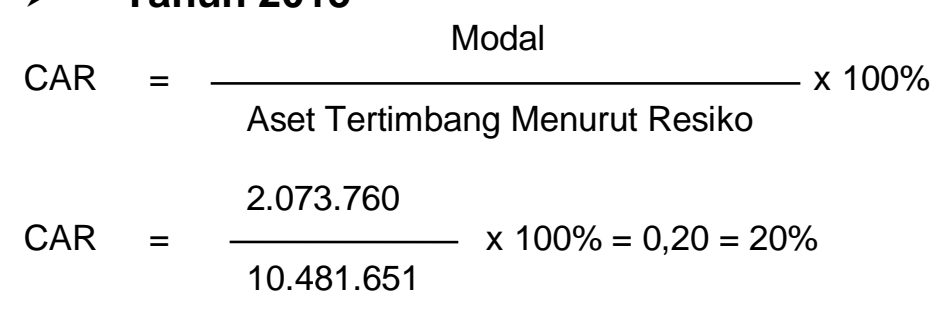

Berdasarkan hasil perhitungan CAR (Capital Adequacy Ratio) pada tahun 2015, rasio CAR (Capital Adequacy Ratio) yang dicapai Bank Sumsel Babel sebesar $20 \%$ yang berarti Bank Sumsel Babel pada tahun 2015 menyediakan 20\% dari 
investasinya untuk setiap aset tertimbang menurut resiko (ATMR) sejumlah $100 \%$ maka Bank Sumsel Babel membiayai dengan modal sebesar $20 \%$.

Tabel Hasil Perhitungan CAR (Capital Adequacy Ratio)
Bank Sumsel Babel Tahun 2011-2015
\begin{tabular}{|c|c|c|}
\hline No & Tahun & $\begin{array}{c}\text { CAR (Capital Adequacy } \\
\text { Ratio) }\end{array}$ \\
\hline 1. & 2011 & $12 \%$ \\
\hline 2. & 2012 & $14 \%$ \\
\hline 3. & 2013 & $15 \%$ \\
\hline 4. & 2014 & $18 \%$ \\
\hline 5. & 2015 & $20 \%$ \\
\hline
\end{tabular}
Sumber : Data diolah 2017

\section{E. PEMBAHASAN}

Menurut Herman Darmawi (2011:210) kesehatan bank merupakan kepentingan semua pihak yang terkait, baik pemilik, manajemen, masyarakat pengguna jasa bank dan pemerintah dalam hal ini Bank Indonesia selaku otoritas pengawas perbankan, karena kegagalan dalam industri perbankan akan berdampak buruk terhadap perekonomian Indonesia.

\begin{tabular}{|c|c|c|c|c|c|c|}
\hline \multirow{2}{*}{ TAHUN } & \multicolumn{7}{|c|}{ RASIO KEUANGAN } \\
\cline { 2 - 7 } & LDR & NPL & BOPO & ROA & ROE & CAR \\
\hline $\mathbf{2 0 1 1}$ & $76 \%$ & $1,5 \%$ & $81 \%$ & $2 \%$ & $26 \%$ & $12 \%$ \\
\hline $\mathbf{2 0 1 2}$ & $77 \%$ & $6,9 \%$ & $84 \%$ & $2 \%$ & $18 \%$ & $14 \%$ \\
\hline $\mathbf{2 0 1 3}$ & $95 \%$ & $9 \%$ & $86 \%$ & $2 \%$ & $13 \%$ & $15 \%$ \\
\hline $\mathbf{2 0 1 4}$ & $89 \%$ & $7,6 \%$ & $82 \%$ & $2 \%$ & $16 \%$ & $18 \%$ \\
\hline $\mathbf{2 0 1 5}$ & $101 \%$ & $4,4 \%$ & $81 \%$ & $3 \%$ & $17 \%$ & $20 \%$ \\
\hline
\end{tabular}

Berdasarkan perhitungan rasio Loan To Deposit Ratio (LDR) selama lima tahun yaitu pada tahun 2011 sampai dengan tahun 2015 Bank Sumsel Babel memperoleh rasio Loan To Deposit Ratio (LDR) yang naik turun. Pada tahun 2011 besar nilai rasio Loan To Deposit Ratio (LDR) 76\%, kemudian pada tahun 2012 nilai rasio Loan To Deposit Ratio (LDR) mengalami kenaikan menjadi 77\%, pada tahun 2013 nilai rasio Loan To Deposit Ratio (LDR) mengalami penurunan menjadi 95\%, pada tahun 2014 nilai rasio Loan To Deposit Ratio (LDR) mengalami kenaikan menjadi 89\% dan pada tahun 2015 nilai rasio Loan To Deposit Ratio (LDR) mengalami penurunan menjadi 101\%. Rasio Loan To Deposit Ratio (LDR) pada tahun 2011 sampai dengan tahun 2015 lebih kecil dari kriteria penilaian tingkat kesehatan bank berdasarkan aspek likuiditas yang ditetapkan oleh Bank Indonesia sebesar $75 \%$. Maka rasio Loan To Deposit Ratio (LDR) yang dicapai Bank Sumsel Babel pada tahun 2011 sampai dengan tahun 2015 dikategorikan dalam kelompok CUKUP SEHAT. Dengan naik turunnya LDR dari tahun 2011 sampai dengan tahun 2015 bank dapat dikatakan belum berhasil menyeimbangkan tingkat rasio dari tahun ketahun. Semoga kedepannya bank dapat menaikkan dan mengedepankannya.

Untuk perhitungan rasio Non Performing Loan (NPL) selama lima tahun yaitu pada tahun 2011 sampai dengan tahun 2015 Bank Sumsel Babel memperoleh rasio Non Performing Loan (NPL) yang naik turun. Pada tahun 2011 besar nilai rasio Non Performing Loan (NPL) 1,5\%, kemudian pada tahun 2012 nilai rasio Non Performing Loan (NPL) mengalami penurunan menjadi 6,9\%, pada tahun 2013 nilai rasio Non 
Performing Loan (NPL) mengalami penurunan kembali menjadi 9\%, pada tahun 2014 nilai rasio Non Performing Loan (NPL) mengalami kenaikan menjadi 7,6\% dan pada tahun 2015 nilai rasio Non Performing Loan (NPL) juga mengalami kenaikan menjadi 4,4\%. Non Performing Loan (NPL) pada tahun 2012 sampai dengan tahun 2015 lebih kecil dari kriteria penilaian tingkat kesehatan bank berdasarkan aspek likuiditas yang ditetapkan oleh Bank Indonesia sebesar 2\%. Kecuali pada tahun 2011 rasio Non Performing Loan (NPL) lebih besar dari kriteria penilaian tingkat kesehatan bank berdasarkan aspek likuiditas yang ditetapkan oleh Bank Indonesia. Maka rasio Non Performing Loan (NPL) yang dicapai Bank Sumsel Babel pada tahun 2011 sampai dengan tahun 2015 dikategorikan dalam kelompok SEDANG KETINGGI. Dengan naik turunnya NPL dari tahun 2011 sampai dengan tahun 2015 bank dapat dikatakan belum berhasil menyeimbangkan tingkat rasio dari tahun ketahun. Semoga kedepannya bank dapat menaikkan dan mengedepankannya.

Hasil perhitungan Rasio Biaya Operasional dengan Pendapatan Operasional (BOPO) selama lima tahun yaitu pada tahun 2011 sampai dengan 2015 Bank Sumsel Babel memperoleh Rasio Biaya Operasional dan Pendapatan Operasional (BOPO) yang stabil dati tahun ketahun. Pada tahun 2011 besar nilai Rasio Biaya Operasional dan Pendapatan Operasional (BOPO) adalah 81\%, kemudian pada tahun 2012 nilai Rasio Biaya Operasional dan Pendapatan Operasional (BOPO) sebesar 84\%, pada tahun 2013 Rasio Biaya Operasional dan Pendapatan Operasional (BOPO) sebesar 86\%, pada tahun 2014 Rasio Biaya Operasional dan Pendapatan Operasional (BOPO) sebesar 82\% dan pada tahun 2015 Rasio Biaya Operasional dan Pendapatan Operasional (BOPO) sebesar 81\%. Rasio Biaya Operasional dan Pendapatan Operasional (BOPO) pada tahun 2011 sampai dengan tahun 2015 lebih kecil dari kriteria penilaian tingkat kesehatan bank yang ditetapkan oleh Bank Indonesia sebesar 90\% maka rasio yang dicapai Bank Sumsel Babel dikategorikan dalam kelompok SANGAT SEHAT. Dengan tingkat rasio yang stabil dari tahun 2011 sampai 2015, itu berarti bank telah berhasil mempertahankan BOPO dari tahun ketahun.

Hasil perhitungan rasio Return On Assets (ROA) selama lima tahun yaitu pada tahun 2011 sampai dengan tahun 2015 Bank Sumsel Babel memperoleh Return On Assets (ROA) pada tingkat stabil. Pada tahun 2011 sampai dengan tahun 2014 rasio Return On Assets (ROA) besarnya nilai rasio yaitu 2\% sama dengan kriteria penilaian tingkat kesehatan bank yang ditetapkan oleh Bank Indonesia berdasarkan aspek rentabilitas sebesar $2 \%$. Sedangkan pada tahun 2015 rasio Return On Assets (ROA) mengalami peningkatan yang signifikan yaitu sebesar $3 \%$. Maka rasio Return On Assets (ROA) yang dicapai Bank Sumsel Babel dikategorikan dalam kelompok SANGAT SEHAT. Dengan tingkat rasio ROA yang baik bank mampu menyeimbangkan bahkan meningkatkan rasio dari tahun ketahun.

Hasil perhitungan rasio Return On Equity (ROE) selama lima tahun yaitu tahun 2011 sampai dengan tahun 2015 Bank Sumsel Babel memperoleh rasio Return On Equity (ROE) yang stabil. Pada tahun 2012 sampai dengan 2015 rasio Return On Equity (ROE) yang diperoleh Bank Sumsel Babel dalam kategori SEHAT, sedangkan pada tahun 2011 rasio Return On Equity (ROE) yang diperoleh Bank Sumsel Babel dalam kategori SANGAT SEHAT. Pada tahun 2011 rasio Return On Equity (ROE) sebesar 26\%, pada tahun 2012 mengalami penurunan dari tahun 2011 sebesar $18 \%$, pada tahun 2013 rasio Return On Equity (ROE) sebesar 13\%, pada tahun 2014 rasio Return On Equity (ROE) sebesar 16\%, dan pada tahun 2015 rasio Return On Equity (ROE) sebesar 17\%. Rasio Return On Equity (ROE) yang dicapai Bank Sumsel 
Babel dari tahun 2011 sampai dengan tahun 2015 berdasarkan kriteria penilaian tingkat kesehatan bank yang ditetapkan oleh Bank Indonesia sebesar 20\% maka dikategorikan dalam kelompok SEHAT. Dengan peningkatan yang stabil dari tahun 2011 sampai dengan tahun 2015, itu berarti bahwa bank telah berhasil mempertahankan ROE dari tahun ketahun.

Berdasarkan hasil perhitungan Rasio Permodalan selama lima tahun yaitu pada tahun 2011 sampai dengan 2015 Bank Sumsel Babel memperoleh CAR (Capital Adequacy Ratio) yang terus mengalami peningkatan. Nilai rasio CAR (Capital Adequacy Ratio) pada tahun 2011 sebesar 12\%, pada tahun 2012 sebesar 14\%, pada tahun 2013 sebesar $15 \%$, pada tahun 2014 sebesar $18 \%$ dan pada tahun 2015 sebesar 20\%. Rasio Permodalan selama tahun 2011 sampai dengan tahun 2015 berdasarkan kriteria tingkat penilaian kesehatan bank yang ditetapkan oleh Bank Indonesia sebesar 20\% maka rasio CAR (Capital Adequacy Ratio) yang diperoleh Bank Sumsel Babel dikategorikan dalam kelompok SANGAT SEHAT. Peningkatan nilai rasio CAR (Capital Adequacy Ratio) ini menunjukkan adanya peningkatan pada jumlah modal dan peningkatan jumlah aset tertimbang menurut resiko (ATMR) yang cukup besar dari tahun 2011 sampai dengan tahun 2015, maka dapat dikatakan bank berhasil mempertahankan nilai rasio CAR. Hal ini dapat tercapai karena bank sangat memperhatikan faktor-faktor eksternal dan semoga kedepannya bank dapat terus mempertahankannya.

\section{F. KESIMPULAN DAN SARAN}

1) Kesimpulan

Berdasarkan hasil analisis kinerja keuangan pada Bank Sumsel Babel pada tahun 2011 sampai dengan tahun 2015, dapat ditarik kesimpulan sebagai berikut :

a) Nilai Rasio LDR (Loan To Deposit Ratio) Bank Sumsel Babel pada tahun 2011 dan 2012 sebesar 76\% dan $77 \% \leq 85 \%$ dikategorikan dalam kelompok SEHAT. Sedangkan Rasio LDR (Loan To Deposit Ratio) pada tahun 2013 dan 2014 sebesar 95\% dan $89 \% \leq 100 \%$ dikategorikan dalam kelompok CUKUP SEHAT. Pada tahun 2015 Rasio LDR (Loan To Deposit Ratio) sebesar 101\% $\leq$ $120 \%$ dikategorikan dalam kelompok KURANG SEHAT.

Rasio NPL (Non Performing Loan) Bank Sumsel Babel pada tahun 2011 sebesar $1,5 \% \leq 2 \%$ dikategorikan dalam kelompok RENDAH, pada tahun 2012 dan 2014 sebesar 6,9\% dan 7,6 $\leq 8 \%$ dikategorikan dalam kelompok SEDANG KETINGGI, pada tahun 2013 sebesar $9 \% \geq 8 \%$ dikategorikan dalam kelompok TINGGI, dan pada tahun 2015 sebesar $4,4 \% \leq 5 \%$ dikategorikan dalam kelompok SEDANG.

b) Rasio BOPO (Biaya Operasional Pendapatan Operasional) Bank Sumsel Babel pada tahun 2011, 2012, 2013, 2014 dan 2015 sebesar 81\%, 84\%, 86\%, 82\% dan $81 \% \leq 90 \%$ dikategorikan dalam kelompok SANGAT SEHAT.

Rasio ROA (Return On Assets) Bank Sumsel Babel pada tahun 2011, 2012, 2013, 2014 dan 2015 sebesar 2\%, 2\%, 2\%, 2\% dan 3\% $\geq 2 \%$ dikategorikan dalam kelompok SANGAT SEHAT.

Rasio ROE (Return On Equity) Bank Sumsel Babel pada tahun 2011 sebesar $26 \% \geq 20 \%$ dikategorikan dalam kelompok SANGAT SEHAT, sedangkan pada tahun 2012, 2013, 2014 dan 2015 sebesar 18\%, 13\%, 16\% dan $17 \% \leq 20 \%$ dikategorikan dalam kelompok SEHAT.

c) Rasio CAR (Capital Adequacy Ratio) Bank Sumsel Babel pada tahun 2011 dan 2012 sebesar $12 \%$ dan $14 \% \leq 15 \%$ dikategorikan dalam kelompok SEHAT, 
sedangkan pada tahun 2013, 2014 dan 2015 sebesar 15\%, 18\% dan $20 \% \geq$ $15 \%$ dikategorikan dalam kelompok SANGAT SEHAT.

\section{2) Saran}

Berdasarkan permasalahan pada PT. Bank Pembangunan Daerah Sumatera Selatan dan Bangka Belitung mengenai kinerja keuangan, maka penulis mencoba memberikan saran untuk permasalahan tersebut, antara lain :

a) Untuk Rasio LDR pada tahun 2015 dikategorikan dalam kelompok kurang sehat, sebaiknya bank tidak hanya bertumpu pada dana masyarakat namun juga harus mencari dari pinjaman lain agar lebih liquid dalam mengembalikan dana masyarakat. Atau dengan menahan pemberian kredit sebelum adanya dana pihak ketiga. Serta untuk lebih memberikan kriteria khusus pada debitur sebelum memberikan kredit sehingga dapat mencegah naiknya tingkat kredit bermasalah / kredit macet.

b) Hampir sebagian besar Rasio Rentabilitas pada Bank Sumsel Babel termasuk dalam kategori sangat sehat, sehingga kinerja Bank Sumsel Babel agar lebih ditingkatkan untuk mempertahankannya.

c) Rasio Kecukupan Modal pada Bank Sumsel Babel termasuk dalam kategori sangat sehat, sehingga kinerja Bank Sumsel Babel agar lebih ditingkatkan untuk mempertahankannya.

\section{DAFTAR PUSTAKA}

Bank Indonesia,2011,UU No. 7 tahun 1992, tentang Perbankan,Jakarta.

Brigham, Eugene F dan Houston, Joel F. 2013. Dasar-Dasar Manajemen Keuangan. Edisi 11 Buku 2 Jakarta: Salemba Empat.

Darmawi, Herman.2011. Manajemen Perbankan. Jakarta: Bumi Aksara.

Fahmi,Irham.2013. Analisis Laporan Keuangan.Bandung:Alfabeta.

Gitman, Lawrence J dan Cahd J. Zutter. 2012. Principles of Managerial Finance. 13th Edition. Global Edition: Pearson Education Limited.

Harahap,Sofian Safri,2011.Teori Akuntansi Edisi Revisi 2011.Jakarta:Rajawali Pers.

,2013. Analisis Kritis Atas Laporan Keuangan,.Cetakan Kesebelas. Rajawali Pers: Jakarta.

Hartono. 2011. Metodologi Penelitian. Zanafa: Pekanbaru.

Hery.(2012).Analisis Laporan Keuangan. Jakarta: Bumi Aksara.

IAI,2010, Standar Akuntansi Keuangan, Salemba Empat, Jakarta.

Jumingan. 2011. Analisis Laporan Keuangan. Jakarta: Bumi Aksara. 
Kasmir, 2010. Bank dan Lembaga Keuangan Lainnya.Raja Grafindo Pers. Jakarta 2014. Analisis Laporan Keuangan. Edisi Satu.Cetakan Ketujuh. Jakarta: PT. Raja Grafindo Persada.

Mudrajad, Kuncoro dan Suhardjono.(2011). Manajemen Perbankan Teori dan Aplikasi. Yogyakarta: BPFE Yogyakarta.

Munawir, S. 2010. Analisis Laporan Keuangan Edisi Keempat.Cetakan kelima belas. Yogyakarta, Liberty.

Munawir, S. 2012. Analisis Informasi Keuangan, Liberty, Yogyakarta.

Riyanto, Bambang. 2011. Dasar - Dasar Pembelajaran Perusahaan.Edisi keempat. BPFF: Yogyakarta.

Subramanyam. K. R dan John J. Wild. 2014. Analisis Laporan Keuangan. Penerjemah Dewi Y. Jakarta: Salemba Empat.

Sudirman, I Wayan,2013.Manajemen Perbankan,Edisi kedua,Kencana.Jakarta.

Sugiyono. 2012. Metode Penelitian Kuantitatif Kualitatif dan R\&D. Bandung: Alfabeta. 2013. Metode Penelitian Manajemen. Bandung: Alfabeta.

Bank Sumsel Babel (2015). Laporan Keuangan dan Kegiatan Perusahaan PT. Bank Pembangunan Daerah Sumatera Selatan dan Bangka Belitung. Dari (http://www.banksumselbabel.com) 